ベントス研連誌 $9 / 10 \quad 1975$

千々石湾海域におけるクモヒトデ類の生態分布

\author{
㐘 池 泰 二 \\ (九州大学理学部 天草臨海実験所)
}

\title{
Ecological distribution of ophiuroids in Chijiwa Bay, West Kyushu Taiji KIKUCHI
}

野母・島原両半島と天草下島に囲を九た千々石湾海域は、東は狭い早崎海峡によって有明海と通 し、南西方向は外海に向って大きく開き対馬暖流系の外洋水の影響を強く受けている。湾奥は水深 $30 \sim 40 m$ の平坦な泥底からなり湾の主部から湾口部にかけては水哚 $50 \sim 60 m$ の細砂底がひ ろがっている。長崎県側は潮流がゆるやかでシルト分の多い軟泥底、砂泥底であるが、天草側の富 岡半島周辺および早崎海峡は、干满差の大きい有明海と外海との間の海水流動がはげしいため局地 的には岩礁底や転石底、その周辺には粗い貝砂底がひろがっている。

筆者は1960年以降この海域においてベントスの調査をおこなっているが、1961～6 3 年 には千々石湾全域にわたり格子目状に観測点を設定しドレッジ採集により半定量調査をおこなった。 また天草臨海実験所のある天草下島北 西端の富岡湾においては、若干の定点 においてドレッジにより 20 ケ月間毎 月採集をおこなったほか数多くのグラ ブ式採泥器採集もおこなわれている。 今回はこれらの資料中からクモヒトデ 類に関する資料のみを抜き㔹して示す。

この海域で今までに採集されたクモ ヒトデ類は 10 科 31 属 50 種におよ んでいる (Murakami, 1944; Irimura, 1969 )。今回は各種の採集地点とその 採集量(ドレッジによる試料は採集面 積、効率が不明なため絶対密度の算出 は不可能であるが、ここでは実際の採 集個体数を 4 段階に分けて標示した)

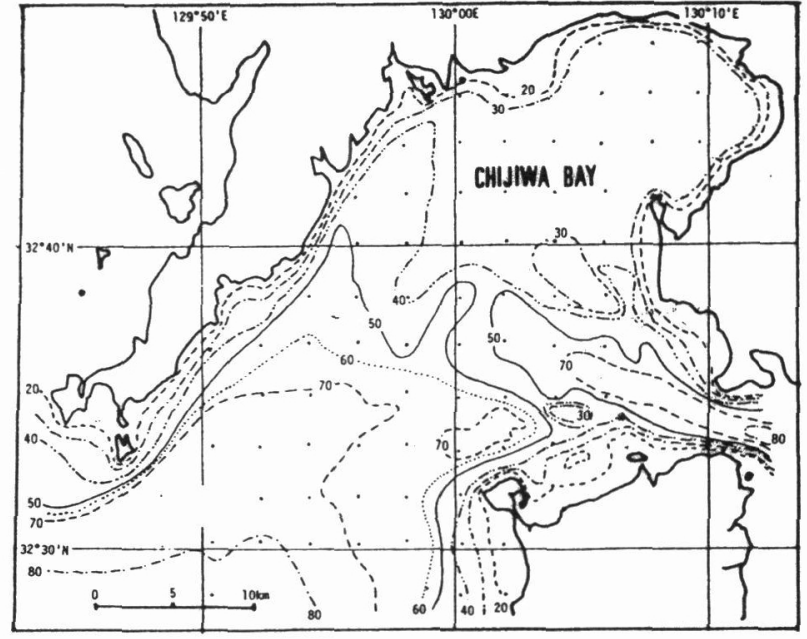

図 1. 千々石湾海域の海底地形 および 1961 年調査の採集地点図。 を地図上の地点に記入し、環境条件と

してはきわめて大まかに媣度と底質の二要因に対する対応仕方を検討した。この海域の無機環境条 件については、今までいくつかの報告があるが、中でも西海区水産研究所の浜田ら(1973 $a, b$, $c, d)$ に上って全域の海況、流況、底質の粒度組成、底泥の焼却減量、有機窒素、有機炭素などが 詳しく調査されている。図 2 の A, B , C は底質粒度の分布と底泥中の有機物焼却減量を前出の文 献より引用したものである。焼却堿量の高い地域範囲は粘土・シルト質の構成比率のもっとも高い 
地城とほとんど一致する。また図には引用しなかったが有機炭素含量、有機窒素含量の分布も焼却 減量の高い地城とほぼ一致する。
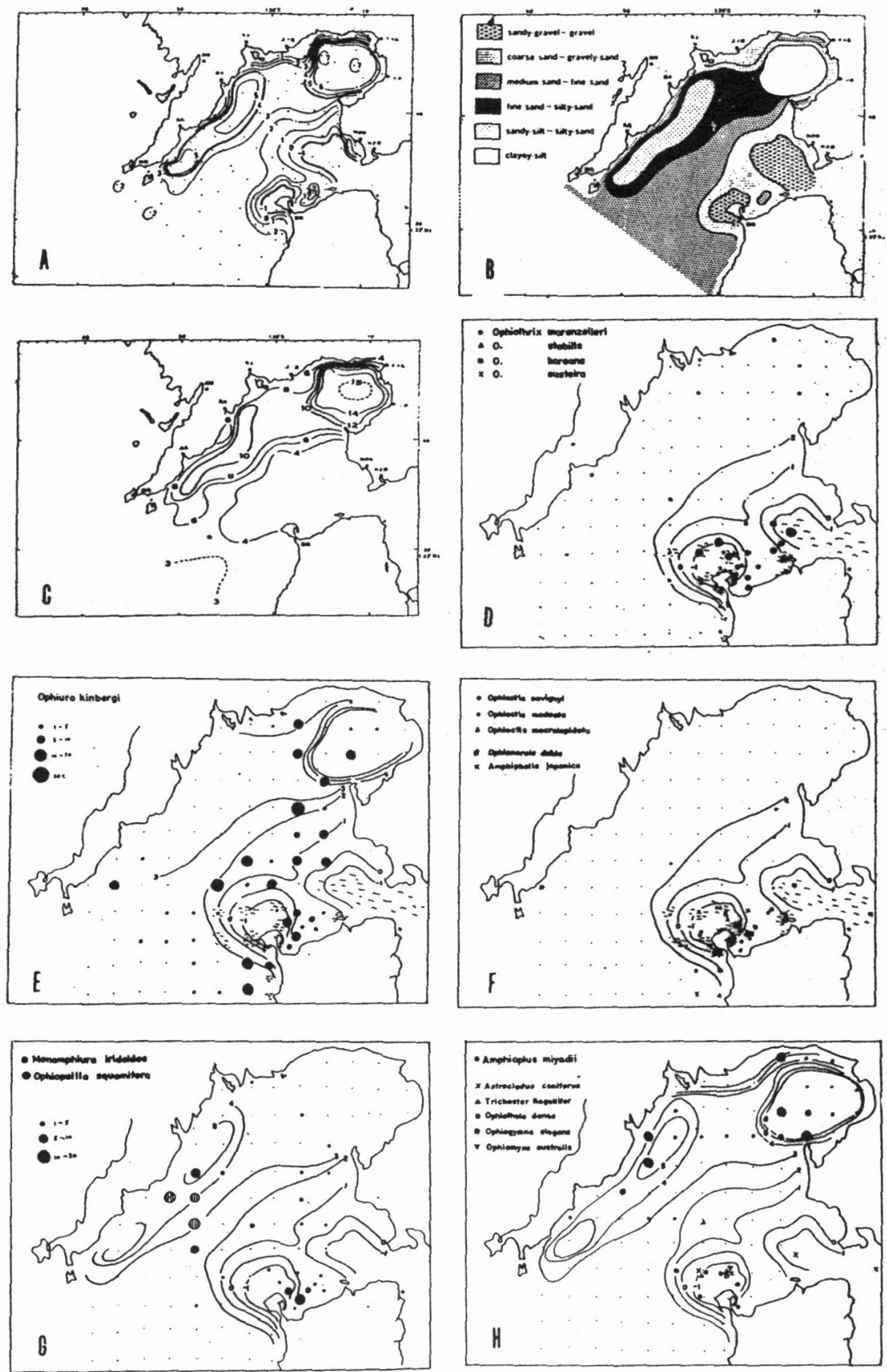

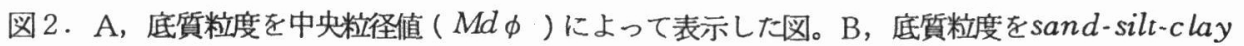
比率で表現した図。C，表層泥の焼却減量（\%)。D〜Hクモヒトデ各種の分布。円の大きさ

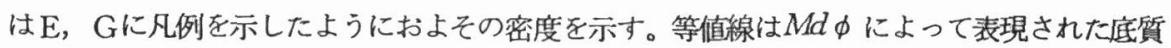
粒度の区分を示す。 
クモヒトデ類の生態的分布パターンを比較すると、潮流の速い天草側の富岡半島外方および早崎 海峡周辺の岩礁底、転石底に集中するOPhiothrix， Ophiactis，これら強流域の海底に着生するヤ ギ類、トサカ類などの腔腸動物に付着する諸種 ( 2 -H図)，上記の強流城には分布しないが員砂 底から砂泥底に(一部は泥底にも)分布するOphiura kinbergi， Monamphiura iridoides などの諸種（図2-E，G）、軟泥底のみに分布するAmphioplus miyadii（図 2-H)などい くつかの底質粒度組成との対応をみることができる。分布がきわめて局地的であるため図 2 には示 せなかったが、典型的な内唀種であるAmphioplus japonicus カキクモヒトデやHemilepis euopla, Ophipeltis aestuarii Icalia syntrachaは、富岡湾の副湾である実験所前面の小入 江巴湾および天草下島中央部の㥓津湾奥部の水深 $10 \mathrm{~m}$ 以浅の軟泥底におい下のみ発見されている。 やや特異な分布を示すものとしては千々石湾主部の $40 \mathrm{~m}$ 以深に限り細砂底から砂泥底、泥底にわ たって分布するOphiopsila squamiferaがある。いずれのグルーブも湾口部の平坦で有機物の少 ない細砂底には稀にしか分布しない。今底質粒度と水樑を二軸にとり、採集されたクモヒトデ諸種 の存在地点をこの図上にプロットして分布域の広狭、重複の状態を模式的に示したのが図 3 である。

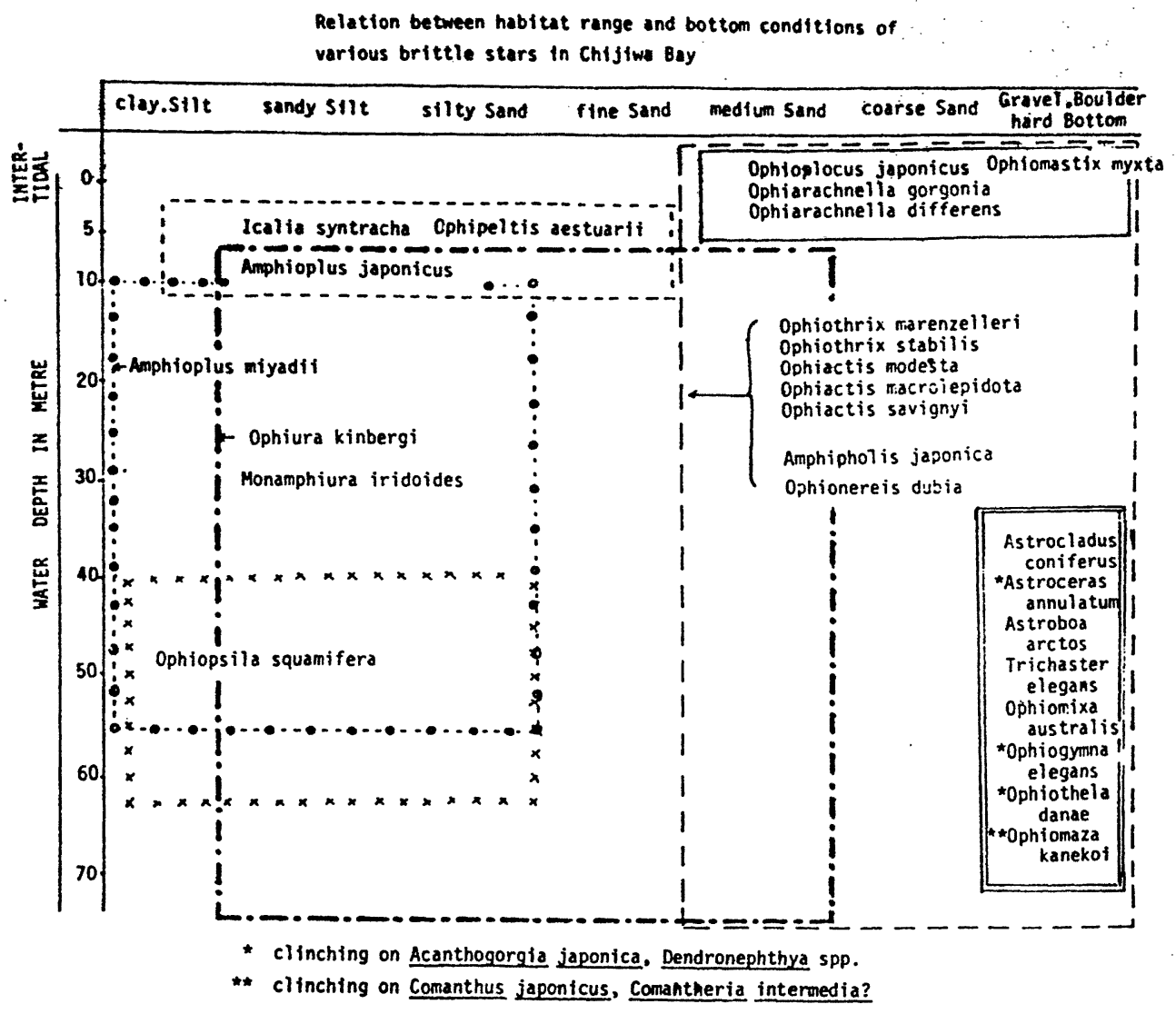

図3.千々石湾海域におけるクモヒトデ各種の生息場所と 底質環境との関係。 
この図ではある種の分布範囲は方形で囲まれているが、実際には分布範囲の中でも高密度で分布す る環境と低密度でしか分布しない所があるので、生息密度の測定が正確にできるなら、等密度線に よる表示で示す方がより望ましい。さらにこのような環境に対する選好を種の属性として一般化す るためにはいくつもの異なった海域での検討が必要であろう。

クモヒトデ類の底質あるいはそれに反映された底層流の強さに対する選好性は現象としての第一 近似であるが、内容としては、クモヒトデ各種の食性、攝食悌式と利用可能な食物との関係が主要 なもののようである。岩礁転石地の潮間帯下部から潮下帯 $(0 \sim 5 m)$ に分布するOphioplocus japonicus, Ophiarachnella gorgoniaなどがこの極浅城で生産され堆積している大型海藻由来 のデトリタスを主な食物としているという相生 (1975，本号所載）の報告はこれらの種の分布状態 とよく合致するし、Ophiothrix トゲクモヒトデ属の諸種注低潮带から70 m以深に到るまで水の 流動の大きい場所に見出されるが、典型的な照濁物食者とされている。筆者の経験でも潮の動く時 期に採集したナガトゲクモヒトデの腕が多量の粘液におおわれていた例がありこのようにして慗濁 物、プランクトンを捕えるのであろう。同じく強流城にすむテッ゙ルモヅル類も彩濁物食で知られて いるものであるが、ヤギ類、トゲトサカに付着する Ophiothela danae, Ophiogyma elegans の場合は寄主の分泌物を利用しているのか、食害しているものかどうか明らかでない。軟泥底にす むAmphioplus, Ophipeltis, Icalia などのスナクモヒトデ類は長い腕で底表面から食物粒子を 集めると一般にいわれているが、同属またはきわめて近縁な属の種間でもBuchanan(1964)がAmphiura filiformis と…hiajei で示したような提食様式の差があるとすれば、今後具体的な確認が 必要である。Ophiopsila squamifera はその長く纎細な腕からみると前記Amphiura群と同様の 底表デトリタス食者であろうと推測されるが生態の観察例はない。ここで興味のあるのはきわめて 分布籍井の広いOPhiura kinbergi クシノハクモヒトデで、入村(1975)はこの種は砂底に盤を 埋めす腕を水平に屈曲させて有機沈海物を集めると述べている。筆者の限られた観察では、砂底、 貝砂底で採集されたクシノハクモヒトデの胃内からは、石英砂にまじって多数のソコミジンコ類、 少数のヨコエビ、介形類、多毛類、二枚貝稚仔の残䯓がみられたので、少くともある程度の捕食習 性を持っことは確かだと思われる。一方この種が泥底にも進出する.ことは千々石湾ばかりでなく瀬 戸内海でも知られており、有機堆積物の多い泥底と貝砂底などでは異った摂食様式をとっている可 能性もある。これも今後の観察にまたねばならぬ問題である。

このほか 1 月のシンポジゥムにおいては、クモヒトデ稚仔の局地的集中と微細な流況条件の問題 限られた小地域でのカキクモヒトデの個体群消長と成長、生活環の長さについてふれたが本稿では 割愛する。 